Research Paper》

\title{
Evidences of in Situ Remediation from Long Term Monitoring Data at a TCE-contaminated Site, Wonju, Korea
}

\author{
Seong-Sun Lee ${ }^{1} \cdot$ Hun-Mi Kim ${ }^{1} \cdot$ Seung Hyun Lee ${ }^{1} \cdot J_{a e-H a ~ Y^{2}{ }^{2}}$ \\ Youn Eun Koh ${ }^{1} \cdot$ Kang-Kun Lee ${ }^{1 *}$ \\ ${ }^{1}$ School of Earth and Environmental Sciences, Seoul National University \\ ${ }^{2}$ Water Industry Research Center, Jeju Special Self-Governing Province Development Corp.
}

\begin{abstract}
The contamination of chlorinated ethenes at an industrial complex, Wonju, Korea, was examined based on sixteen rounds of groundwater quality data collected from 2009 to 2013. Remediation technologies such as soil vapor extraction, soil flushing, biostimulation, and pumping-and-treatment have been applied to eliminate the contaminant sources of trichloroethylene (TCE) and to prevent the migration of TCE plume from remediation target zones. At each remediation target zone, temporal monitoring data before and after the application of remediation techniques showed that the aqueous concentrations of TCE plume present at and around the main source areas decreased significantly as a result of remediation technologies. However, the TCE concentration of the plumes at the downstream area remained unchanged in response to the remediation action, but it showed a great fluctuation according to seasonal recharge variation during the monitoring period. Therefore, variations in the contaminant flux across three transects were analyzed. Prior to the remediation action, the concentration and mass discharges of TCE at the transects were affected by seasonal recharge variation and residual DNAPLs sources. After the remediation, the effect of remediation took place clearly at the transects. By tracing a time-series of plume evolution, a greater variation in the TCE concentrations was detected at the plumes near the source zones compared to the relatively stable plumes in the downstream. The difference in the temporal profiles of TCE concentrations between the plumes in the source zone and those in the downstream could have resulted from remedial actions taken at the source zones. This study demonstrates that long term monitoring data are useful in assessing the effectiveness of remediation practices.
\end{abstract}

Key words : Chlorinated ethene, Trichloroethylene (TCE), Long term monitoring, Remediation, Groundwater

\section{Introduction}

Trichloroethylene (TCE) is one of the most frequently detected contaminants at high concentrations due to its widespread usage as a degreasing and cleaning agent in various commercial applications in the industrial area of Korea. Due to its hazard effect in human health (Gist and Burg, 1995), effective remediation methods of groundwater sites contaminated with chlorinated ethenes such as TCE need to be established (Jackson, 2004). The Korea Ministry of Environment (KMOE) commenced intense monitoring at selected contaminated sites within industrial complexes and near chemical storage facilities. The Woosan industrial complex (WIC) is a typical example of an intensely monitored contaminated site, which has drawn considerable attention from KMOE as well as the public media (Yang et al., 2012). With the financial support from KMOE, a project team called 'SEEDS groundwater research team' has initiated a 5year GAIA (Geo-Advanced Innovative Action) project on the development of remediation technologies to restore contaminated groundwater at WIC.

The remediation methods for decontamination of chlorinated ethenes on a field scale include soil vapor extraction (SVE), soil flushing, pumping-and-treatment, and injection of nanoscale zerovalent iron (nZVI) (Gordon, 1998; Mackay et al., 2000; Rivett et al., 2006; Wei et al., 2010; McCray et al., 2011). Long term monitoring data have been used to evaluate the occurrence of natural attenuation or the long

*Corresponding author : kklee@snu.ac.kr

Received : 2013.9.24 Reviewed:2013.11.21 Accepted:2013. 11.21

Discussion until : 2014. 1.31 
term effectiveness of remediation techniques (McGuire et al., 2004; McGuire et al., 2006; Phillips et al., 2010). Previous studies have assessed the remediation efficiency based on the monitoring data, most of which were obtained from near-source zones. For the better management of groundwater resources, the intensive monitoring of water systems on a catchment scale (from a contaminant source to the downstream region) is required for the groundwater quality protection (Conant et al., 2004; Chapman et al., 2007). Moreover, mass flux approaches (monitoring the concentration of contaminants in aqueous phase due to source zone DNAPL-groundwater mass transfer) have been used to evaluate the source zone remediation efficiency (Soga et al., 2004; Brusseau et al., 2013) and to understand the natural attenuation mechanisms (Chapman et al., 2007; Basu et al., 2009). The spatial and temporal variations of mass fluxes at contaminated sites can provide an effective tool for evaluating the effectiveness of remediation technologies and for envisioning the temporal evolution of contaminant plumes (Einarson and Mackay, 2001).

In this study, the TCE concentration in plumes near WIC and its mass discharge were monitored at three transects perpendicular to the dominant groundwater flow, and they were evaluated along with sixteen rounds of groundwater quality data at about 100 monitoring wells from May 2009 to August 2013. In WIC, several remediation actions such as pumping-and-treatment, soil flushing, and development of a in-situ reactive zone using nZVI injection have been employed to cleanup the TCE contaminant source and to prevent the spread of the contaminant plume from the source zone. The purpose of this study was to assess the effectiveness of the remediation technologies applied at WIC using the long term data on the variation of TCE concentration and its mass discharge.

\section{Materials and Field Sampling Methods}

\subsection{Site Description and History}

The study site is located in Wonju city, about 120-km eastward of Seoul, Korea. As shown in Fig. 1, this site covers the Road Administrative Office (RAO) of Gangwon Province, Woosan industrial complex (WIC), with the Wonju stream flowing from west to east. In the western part of the study area, RAO is located at the altitude of $135 \mathrm{~m}$ above the mean sea level (MSL) and surrounded by small mountains, forest, and grass areas. Groundwater recharge is likely to occur through unpaved regions around the RAO. Most area of WIC is paved (91\% of the area) and located at the downhill of the RAO with relatively low altitude $(118 \mathrm{~m}$, MSL). Due to the paved surfaces, only a small portion of rainfall is recharged into groundwater. The dominant groundwater flow direction is from the RAO to the Wonju stream.

The study area has been heavily contaminated by multiple DNAPL components such as trichloroethylene (TCE) and tetrachloride (CT) (Yang et al., 2012) (Fig. 2). During the GAIA project period, the intensive monitoring of groundwater quality data has been performed using 101
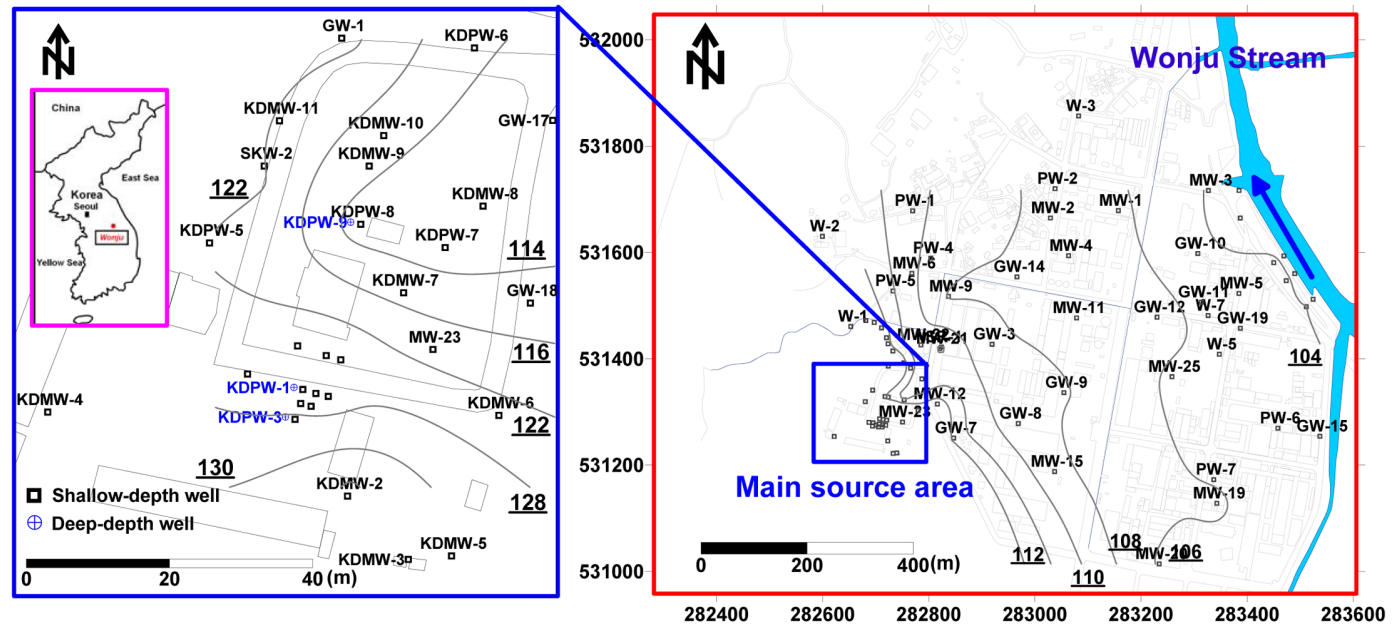

Fig. 1. Location of study area showing main source area, monitoring wells, and groundwater level measured in August 2013. 
monitoring wells (51 wells pre-existed before the GAIA project were imitated plus 50 wells newly installed thereafter). Fig. 1 shows the location of groundwater monitoring wells in this area.

For the first 2 years of the GAIA project period (years 2009-2010), 8 potential source locations responsible for various plumes were identified by Yang et al. (2012, 2013), and they also reported that some DNAPL sources existed above the groundwater table, which sporadically affects the groundwater quality by recharge. Fig. 2 represents the location of the main contaminant sources near the RAO and the other small sources.

Several remediation technologies have been employed to

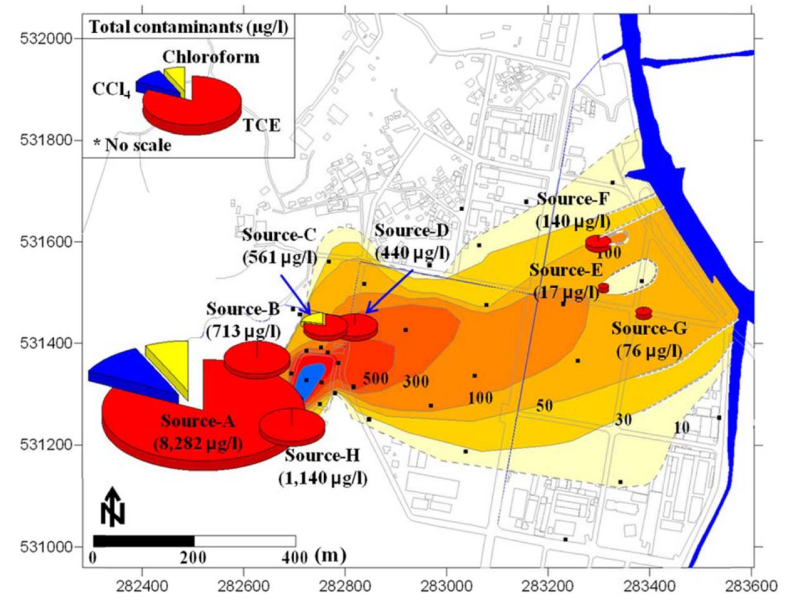

Fig. 2. Locations of potential source zones identified using chemical fingerprinting and hydrological response analysis (Yang et al., 2012). eliminate the contamination sources. For the remediation of the main source area (A zone), soil vapor extraction, soil flushing, and biostimulation techniques were applied. Also, nZVI was injected to reduce the TCE concentration near another source area (B zone). In the $\mathrm{C}$ zone, pump-and-treat method was implemented to prevent the migration of TCE plumes from the RAO to WIC and reduce dissolved TCE concentration (see Fig. 3).

To evaluate the effectiveness of the remedial actions, the concentrations of TCE, CT and CF dissolved in groundwater have been monitored for 5 years. The TCE concentrations were compared before and after implementing the remediation actions.

\subsection{Hydrogeological Conditions}

The subsurface of the RAO source zone consists of an unconsolidated soil layer, a weathered rock, and an intact Jurassic biotite granite. Both the soil layer and the weathered rock are approximately $30 \mathrm{~m}$ thick. In this study, the elevation of the top of the low permeability crystalline, biotite granite is $120 \mathrm{~m}$ above the MSL, and the water table measured on August 8, 2013 is $124.24 \mathrm{~m}$ high above the MSL.

Precipitation data were obtained for the last 5 year period beginning from September 2008 from the Wonju meteorological station (Fig. 4). For the last 5 years, 1,562 $\mathrm{mm}$ of the average annual rainfall was observed, $75 \%$ of which was concentrated in the rainy season (June to September) as shown in Fig. 2. Elevated groundwater levels likely resulted

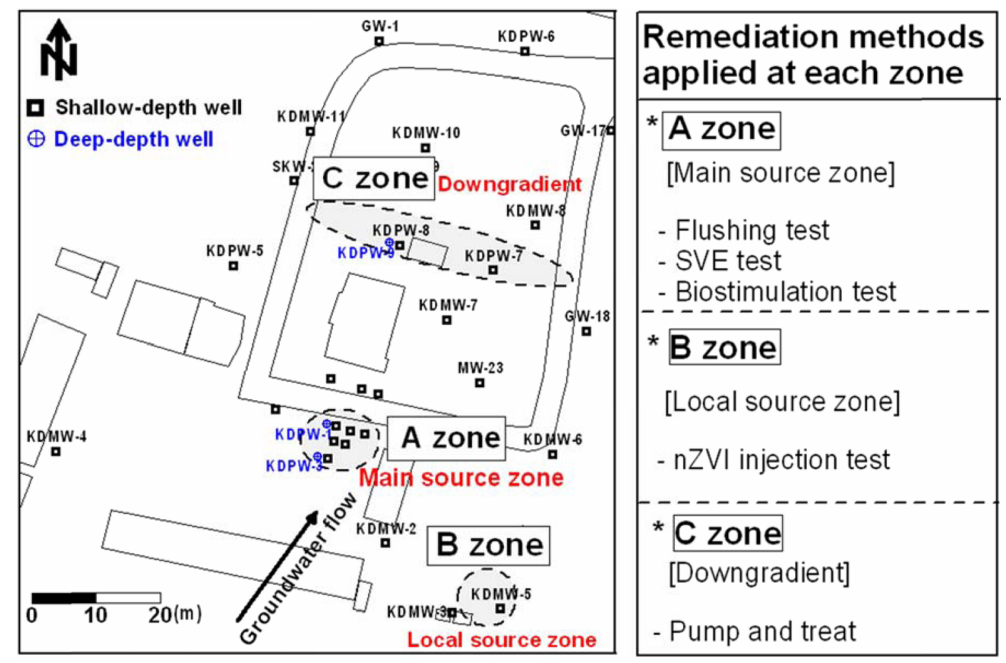

Fig. 3. Remediation target zone and remediation methods applied at each target zone. 


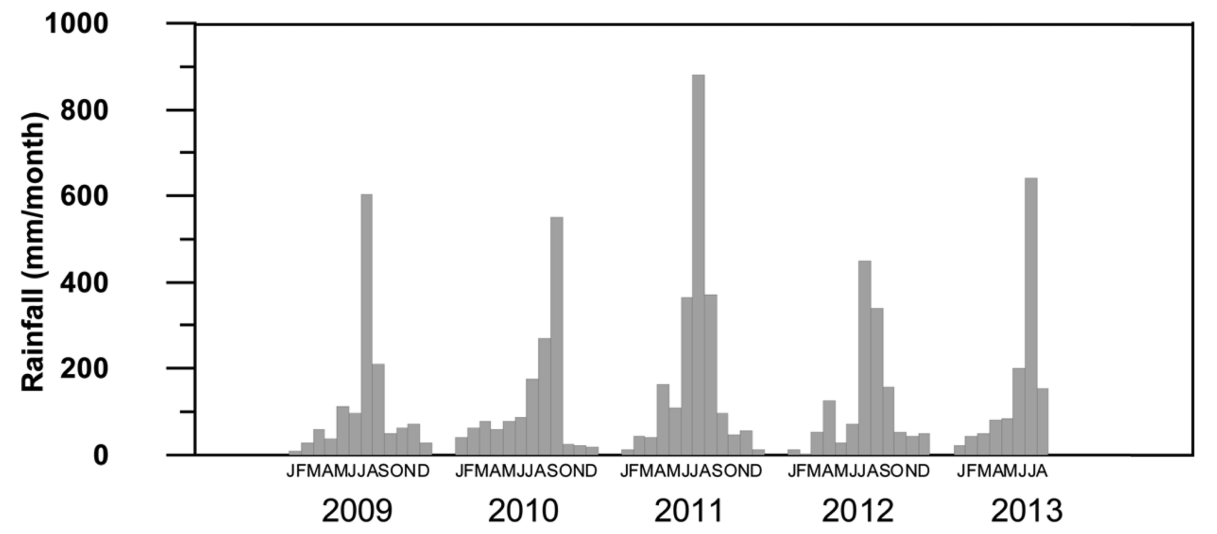

Fig. 4. Precipitation in Wonju for 5 years (2009-2013).

Table 1. Average monthly rainfall and temperature for 5 years (September 2008 - August 2013)

\begin{tabular}{|c|c|c|c|c|c|c|c|c|c|c|c|c|c|}
\hline & Jan & Feb & Mar & Apr & May & Jun & Jul & Aug & Sep & Oct & Nov & Dec & Ave \\
\hline $\begin{array}{l}\text { Average rainfall } \\
(\mathrm{mm} / \mathrm{month})\end{array}$ & 18.4 & 35.2 & 54.8 & 93.3 & 81.7 & 163.2 & 550.3 & 268.0 & 188.0 & 41.7 & 40.8 & 27.2 & 130.2 \\
\hline $\begin{array}{l}\text { Average temperature } \\
\left({ }^{\circ} \mathrm{C}\right)\end{array}$ & -5.0 & 0.1 & 5.0 & 11.1 & 18.3 & 23.2 & 25.4 & 26.3 & 20.5 & 13.5 & 6.4 & -2.0 & 11.9 \\
\hline $\begin{array}{l}\text { Average high } \\
\text { temperature }\left({ }^{\circ} \mathrm{C}\right)\end{array}$ & 0.6 & 5.8 & 10.8 & 17.6 & 24.6 & 29.0 & 29,8 & 31.1 & 26.3 & 20.3 & 11.9 & 3.1 & 17.6 \\
\hline $\begin{array}{l}\text { Average low } \\
\text { temperature }\left({ }^{\circ} \mathrm{C}\right)\end{array}$ & -10.2 & -4.9 & -0.4 & 5.0 & 12.3 & 18.0 & 22.1 & 22.5 & 16.0 & 8.1 & 1.6 & -6.5 & 7.0 \\
\hline
\end{tabular}

in the contact of the residual DNAPL sources above the water table with groundwater along with increased hydraulic gradients. Thus, rainfall would facilitate the dissolution of the residual DNAPLs and its migration in the downward.

The average annual temperature during the GAIA period ranged over $11.4-12.3^{\circ} \mathrm{C}$. High average monthly temperatures were observed mainly in August $\left(25.1-27.1^{\circ} \mathrm{C}\right)$, while low average monthly temperatures were observed in January $\left(-7.7-3.7^{\circ} \mathrm{C}\right)$, with about 30 degrees temperature difference between hot and cold seasons. Table 1 shows the rainfall and temperature data.

\subsection{Groundwater Sampling and Water Quality}

\section{Analysis}

Sixteen rounds of groundwater sampling were taken at approximately 100 monitoring wells from May 2009 to August 2013. Especially, the long term monitoring data were collected to evaluate the effectiveness of the applied techniques such assoil flushing and SVE. Prior to groundwater sampling, at least three well-volumes were purged using a low-rate submersible pump attached to a polyethylene hose, and a new hose was replaced at each sampling point to avoid the potential cross-contamination. All groundwater samples were collected in a closed flow-through cell. At the same time, measurements for temperature, $\mathrm{pH}$, dissolved oxygen (DO), electrical conductivity (EC), oxidation reduction potential (ORP) and total dissolved solid (TDS) were performed to evaluate the geochemical properties of groundwater in the field. Also, the groundwater samples for analysis of chlorinated contaminants were directly collected from a continuous water stream into $40 \mathrm{ml}$ amber glass vials sealed with Teflon-lined septa with no headspace. All samples were stored at $4^{\circ} \mathrm{C}$ prior to laboratory analysis, with at least $10 \%$ of them collected in duplicate. GC/MS (Saturn 2100T, VARIAN) was used for the analysis of chlorinated organic contaminants- TCE, CT and CF. Water quality parameters such as cations $\left(\mathrm{Ca}^{2+}, \mathrm{K}^{+}, \mathrm{Mg}^{2+}, \mathrm{Na}^{+}, \mathrm{Si}^{4+}, \mathrm{Fe}^{2+}, \mathrm{Mn}^{2+}\right)$, anions $\left(\mathrm{F}^{-}, \mathrm{Cl}^{-}, \mathrm{NO}_{3}^{-}, \mathrm{SO}_{4}{ }^{2-}, \mathrm{HCO}_{3}^{-}, \mathrm{CO}_{3}{ }^{2-}\right)$, dissolved organic carbon (DOC) were measured at off-site laboratories.

\subsection{Mass Discharge}

A mass discharge is an important parameter used for 
designing an effective remediation scheme and evaluating its performance. The mass discharge of the main contaminant TCE along the groundwater flow path was calculated according to Einarson and Mackay (2001) and Chapman et al. (2007) as follows:

$$
M_{d}=\sum_{i=1}^{n} C_{i} q_{i} A_{i}
$$

where $M_{d}$ is the total TCE mass discharge in mass per time; $C_{i}$ is the linearly interpolated TCE concentration in mass per volume; $n$ is the number of vertical section which is assigned within a transect and $A_{i}$ is the rectangular sub-area formed by discretizing the cross-sectional area of groundwater flow between two adjacent wells aligned along the transect line. The specific discharge of groundwater $\left(q_{i}\right)$ was estimated using the Darcy's law (i.e., $q_{i}=K i$ ), and the hydraulic gradient for each sampling event was calculated with observed head data measured at wells around each transect.

\section{Results and Discussion}

\subsection{Variations in TCE Concentration and its Mass Discharge}

Groundwater of the study area is contaminated by chlorinated solvents, mainly TCE with other chlorinated organics including carbon tetrachloride, chloroform and their degradation by-products. Six representative wells were selected along the groundwater flow direction from the main source area (A Zone) to the Wonju stream. Periodically monitored concentrations of chlorinated organic pollutants for sixteen times were plotted to evaluate their temporal variations (Fig. 5). The highest TCE concentration of $15,748 \mu \mathrm{g} / \mathrm{L}$ was observed at KDPW-02 (August 2009), the monitoring well at the main source area. The highest TCE concentrations at SKW-6, GW-1, MW-22, GW-3, and GW-10 were 7,007 (February 2011), 593 (October 2007), 748 (August 2004), 574 (August 2008), and $112 \mu \mathrm{g} / \mathrm{L}$ (May 2010), respectively, indicating that the contaminants migrate along the groundwater flow direction. The TCE concentration in the main source area gradually decreased over time during the early monitoring period (years 2009-2011), while it dramatically decreased from the end of year 2012 due to the effect of
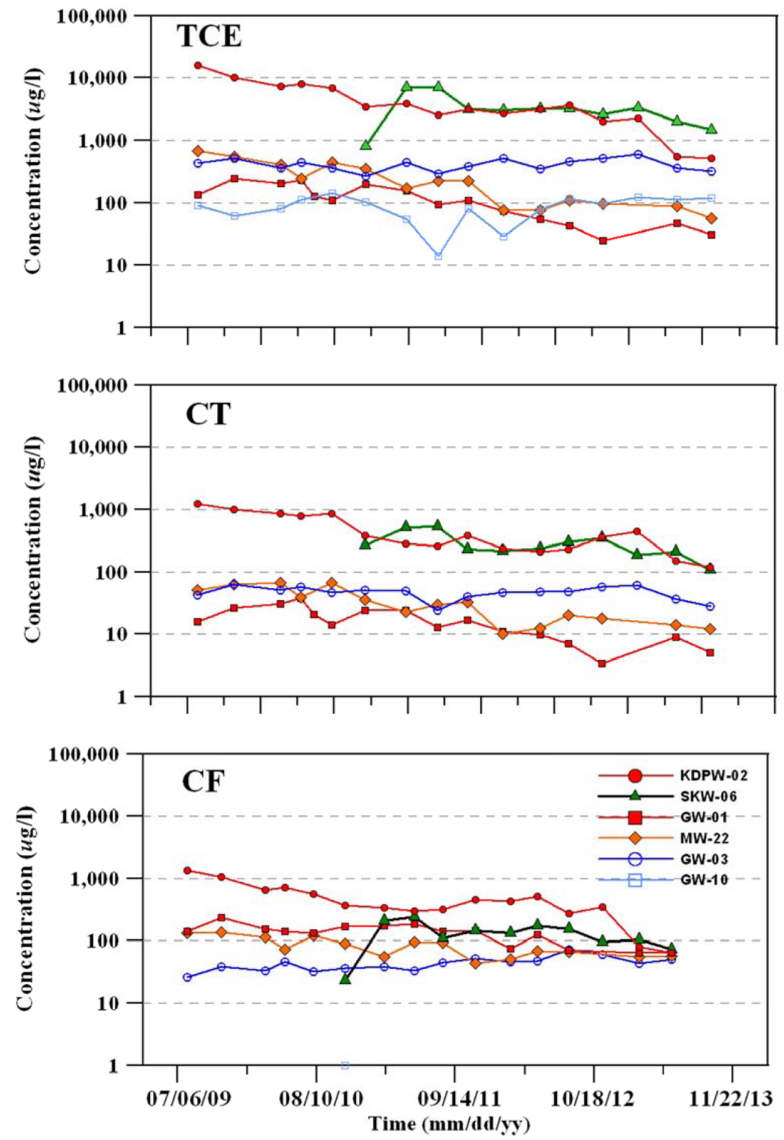

Fig. 5. Seasonal concentration changes of multiple-DNAPL contaminants at selected wells along a groundwater flow path.

remediation. The most recently measured TCE concentration at KDPW-02 was $567 \mu \mathrm{g} / \mathrm{L}$. In the downstream, slightly lower TCE concentrations were observed at GW-1 and MW22 , while the concentrations were maintained in the range of range of $66-377 \mu \mathrm{g} / \mathrm{L}$ at GW-3 and GW-10. The CT and CF concentrations at KDPW-02 showed the similar temporal pattern to the TCE concentration over the period, but they were lower compared to the TCE concentration.

The mass discharge of TCE across the source transect decreased since the remediation actions were implemented (see Fig. 6(b)). Before the remediation actions, the maximum mass discharge was estimated to be $26.58 \mathrm{~g} /$ day. However, after the start of the remediation actions, the average mass discharge was decreased to $2.94 \mathrm{~g} /$ day. In contrast, the calculated mass discharges of TCE at transects- 1 and 2 were correlated with the seasonal variation due to recharge, but they were not affected by the remediation actions. In transect-1, the average mass discharges before and after the 


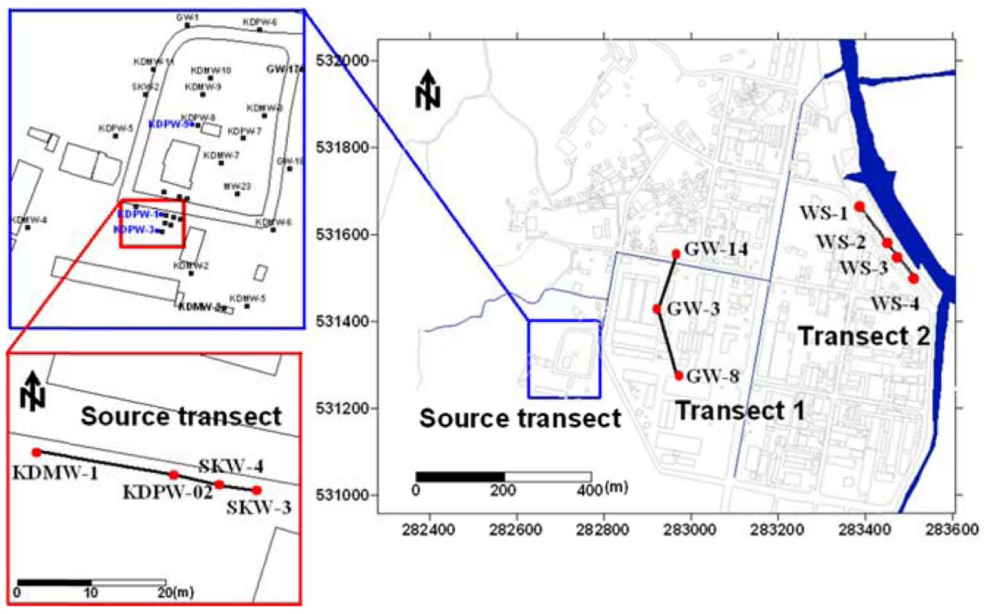

(a)
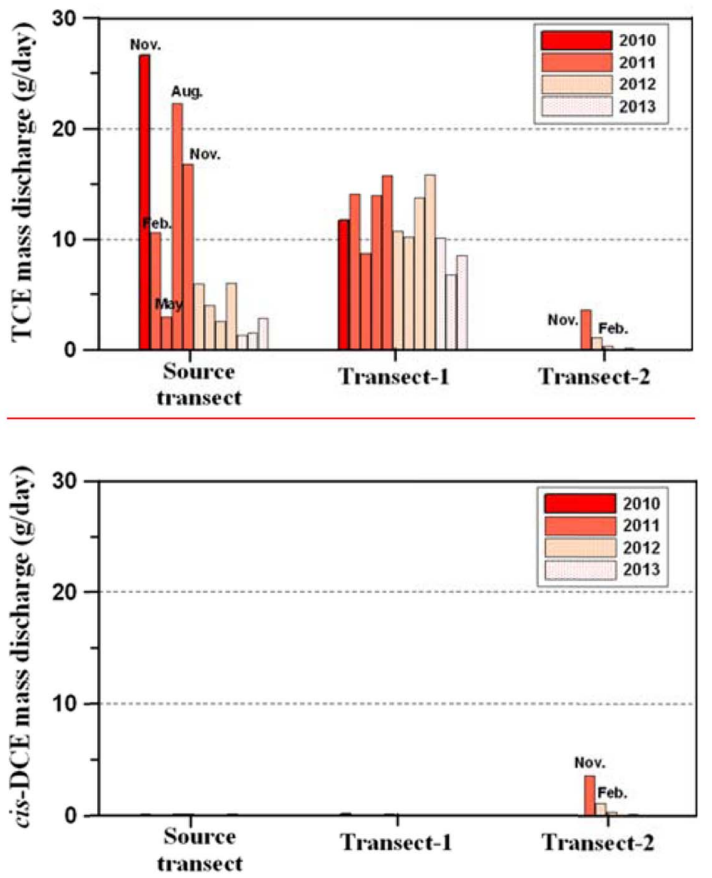

(b)

Fig. 6. Study site showing the transect lines for mass discharge (a) and temporal mass discharge of TCE and cis-DCE plume at each transect (b).

implementations of the remediation actions were estimated to be 12.36 and $10.29 \mathrm{~g} /$ day, respectively. Similarly, the average mass discharges at transect- 2 were estimated to be $0.68 \mathrm{~g} /$ day for before-the-remediation and $0.07 \mathrm{~g} /$ day for after-the-remediation. Based on these distributions of mass discharges, over half of TCE plumes crossing the source transect would reach the middle of the industrial complex (Fig. 6(b)).
The minimal presence of the TCE degradation products such as cis-DCE and VC suggests that little transformation of TCE occurred over a 200 meter long path between the main source area and transect-1. However, near the stream, the biodegradation of TCE may explain the decreased TCE mass flux and the continuous detection of cis-DCE near the stream zone.

The effect of the remediation actions taken at the main 


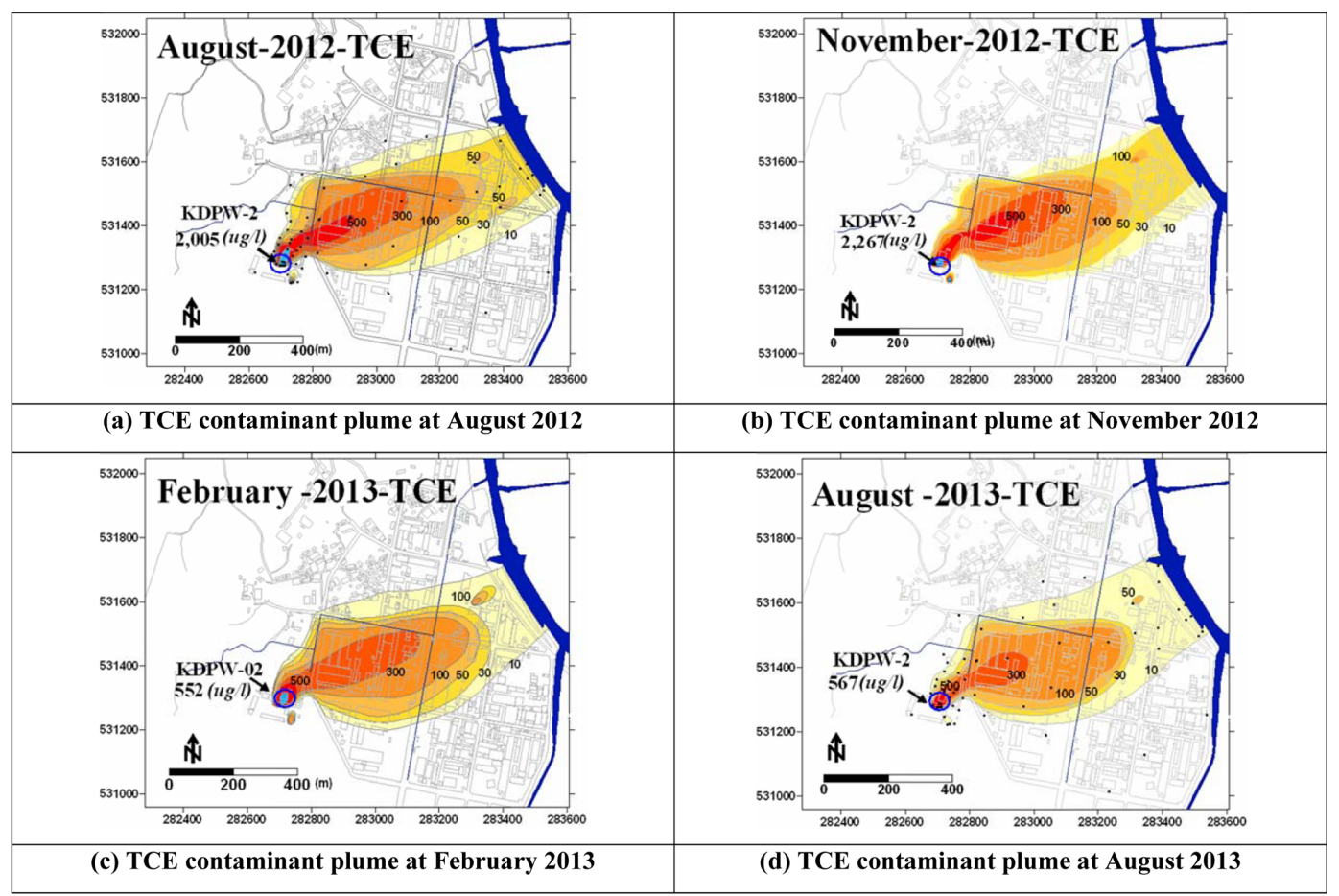

Fig. 7. Comparison of TCE plumes observed during August 2012 and August 2013 field surveys.

source area was not evident at the transect-1 during the monitoring period. Therefore, a longer monitoring is needed to observe the variation of the TCE mass discharge across transects- 1 and 2 as a result of the remediation actions.

\subsection{Comparison of TCE Contaminant Plumes}

In Fig. 7, the temporal changes in the distribution of TCE plumes can be readily seen from the water quality data of the samples collected in August 2012, November 2012, February 2013, and August 2013. The four TCE plumes in Fig. 7 exhibit considerably larger variations in the TCE concentrations near the source zone than in the downstream. Before the remediation actions applied, several high concentration levels of TCE $(2,005 \mu \mathrm{g} / \mathrm{L}$ in August 2012 and 2,267 $\mu \mathrm{g} / \mathrm{L}$ in November 2012) were observed in the plume placed at the main source area. During the remediation, the size of the TCE plume at the downgradient did not change significantly, but the TCE concentration in the plume at the main source area showed the apparent decrease (e.g., from 552 $\mu \mathrm{g} / \mathrm{L}$ in February 2013 to $567 \mu \mathrm{g} / \mathrm{L}$ in August 2013). From these results, the TCE plume representing the high concentration level became smaller in size than previous plumes.

\subsection{TCE Concentration Monitoring at Each}

\section{Remediation Target Zone}

Since remediation technologies were employed to cleanup several target areas the variations of TCE concentration were monitored (Fig. 8). In case of A zone where the highest TCE contamination was encountered, biostimulation, SVE, and flushing methods were applied at the main source area. Before the application of the remediation technologies, monitoring wells in the main source area showed high TCE concentration levels whereas, after the remediation actions applied, the overall TCE concentration was lowered. Especially, at SKW-05, the TCE concentration fell from 1,226 to $3 \mu \mathrm{g} / \mathrm{L}$. In case of B zone, nZVI injection was applied to a local source zone which has the maximum TCE concentration of $32,729 \mu \mathrm{g} / \mathrm{L}$. As a result of nZVI injection, the most dramatic change was observed for the TCE concentration; for example, the maximum TCE concentration dropped below the drinking water standard $(3 \mu \mathrm{g} / \mathrm{L})$ during the 13 day remediation period. At $\mathrm{C}$ zone located in the downward of the main source area, a pump-and-treat method was performed to prevent the further migration of the contaminants from A and B zones. The pump-and-treat method was operated periodically 9 times for the 3 year duration from 2010 

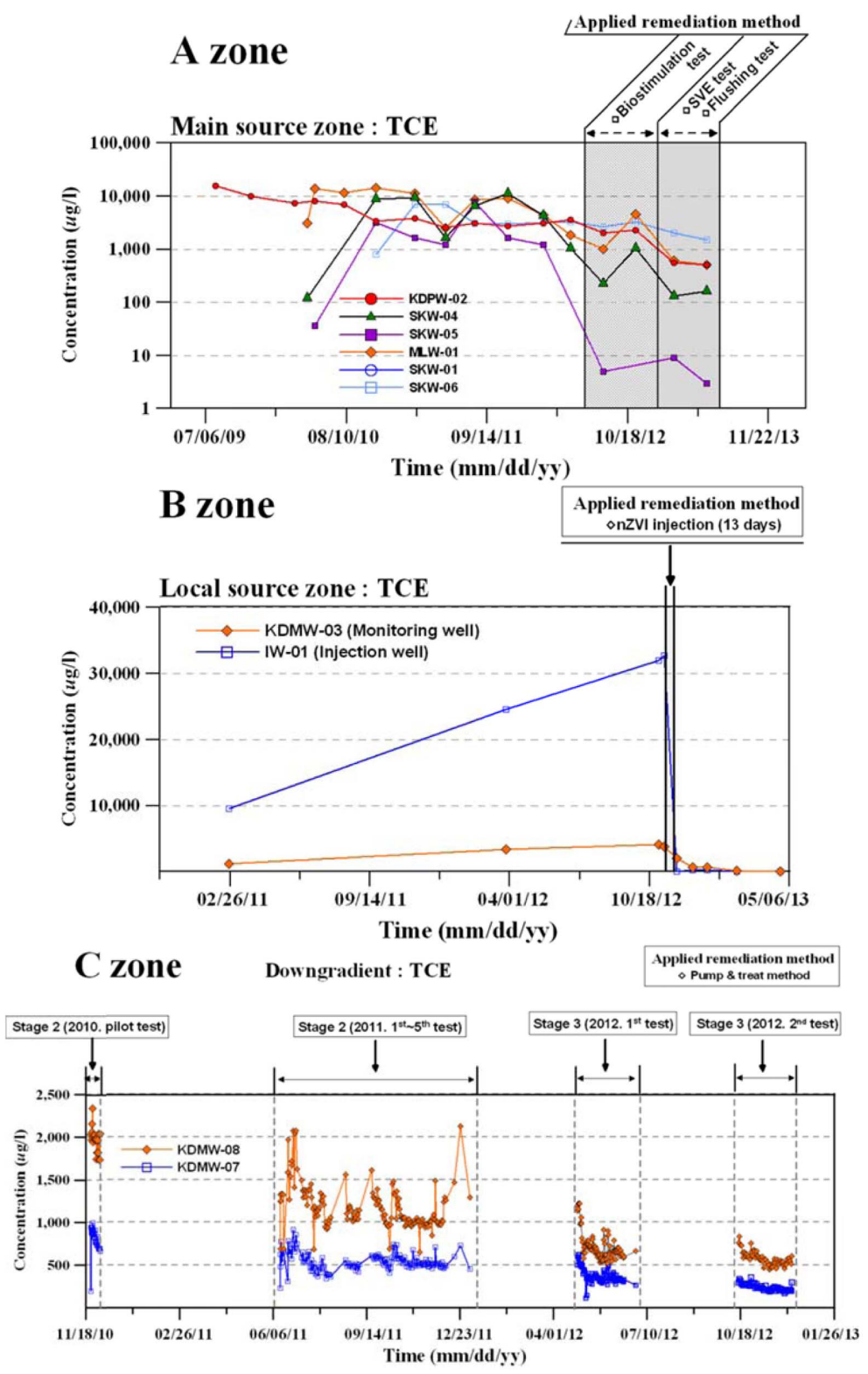

Fig. 8. Results of TCE concentration monitoring observed at each remediation target zone.

to 2012. According to the monitoring data at the pumping wells of KDPW-07 and KDPW-08, TCE concentrations showed gradual decreases due to the remediation action. The initial TCE concentrations in the groundwater were 2,032 $\mu \mathrm{g} / \mathrm{L}$ at KDPW-07 and $941 \mu \mathrm{g} / \mathrm{L}$ at KDPW-08. Over the course of the remediation, the TCE concentrations were decreased to $665 \mu \mathrm{g} / \mathrm{L}$ at KDPW-07 and $297 \mu \mathrm{g} / \mathrm{L}$ at KDPW08. Based on the mass discharge data of TCE at each well, the cumulative mass removal of TCE was estimated to be $5.49 \mathrm{~kg}$ over the remediation period. These results indicated that the pump-and-treat method exercised at $\mathrm{C}$ zone was effective for preventing the migration of the TCE plume from the RAO to WIC.

\section{Summary and Conclusion}

Temporal variations of TCE plumes and the mass discharge of TCE in groundwater at an industrial complex, Wonju, Korea were examined using long term monitoring data. Also, to evaluate the effectiveness of the remediation technologies applied, the variation in the TCE concentrations was analyzed and quantified using the monitoring data. 
The TCE concentrations and its mass discharge through the source transect responded strongly to the applied remediation actions. However, as getting to the downstream from the main source area, the observed variations in the TCE concentration and its mass discharge were mainly controlled by hydrogeological parameters such as seasonally varied recharge. Although the TCE contamination in WIC was not attenuated to a great extent, our study indicates that the source plumes have been contained effectively. The TCE concentration in WIC is expected to decrease in the future as a result of the source zone remediation. In this study, the effectiveness of the remediation actions performed during the GAIA project period was demonstrated using a long term monitoring data set. Such data will be helpful in assessing the long term performance of remediation technologies at a contaminated site.

\section{Acknowledgements}

This project is supported by the Korea Ministry of Environment under "The GAIA Project (173-092-009)".

\section{References}

Basu, N.B., Rao, P.S.C., Poyer, I.C., Nandy, S., Mallavarapu, M., Naidu, R., Davis, G.B., Patterson, B.M., Annable, M.D., and Hatfield, K., 2009, Integration of traditional and innovative characterization techniques for flux-based assessment of dense non-aqueous phase liquid (DNAPL) sites, J. Contam. Hydrol., 105(3-4), 161-172.

Brusseau, M.L., Matthieu III, D.E., Carroll, K.C., Mainhagu, J., Morrison, C., McMillan, A., Russo, A., and Plaschke, M., 2013, Characterizing long term contaminant mass discharge and the relationship between reductions in discharge and reductions in mass for DNAPL source areas, J. Contam. Hydrol., 149, 1-12.

Conant J.B., Cherry, J.A., and Gillham, R.W., 2004, A PCE groundwater plume discharging to a river: influence of the streambed and near-river zone on contaminant distributions, $J$. Contam. Hydrol., 73(1-4), 249-279.

Chapman S.W., Parker B.L., Cherry J.A., Aravena, R., and Hunkeler, D., 2007, Groundwater-surface water interaction and its role on TCE groundwater plume attenuation, J. Contam. Hydrol., 91, 203-232.

Einarson, M.D. and Mackay D.M., 2001, Predicting impacts of groundwater contamination, Environ. Sci. Technol., 35(3), 6673.

J. Soil \& Groundwater Env. Vol. 18(6), p. 8 17, 2013
Gorden, M.J., 1998, Case history of a large-scale air sparging/ soil vapor extraction system for remediation of chlorinated volatile compounds in ground water, Ground Water Monit. Rem., 18(2), 137-149.

Gist, G.L. and Burg J.R., 1995, Trichloroethylene - A review of the literature from a health effects perspective, Toxicol. Ind. Health, 11(3), 253-307.

Jackson, R.E., 2004, Recognizing emerging environmental Problems: The case of chlorinated solvents in groundwater, Technol. Cul., 45(1), 55-79.

Mackay, D.M., Wilson, R.D., Brown, M.J., Ball, W.P., and Durfee, D.P., 2000, A controlled field evaluation of continuous vs. pulsed pump-and- treat remediation of a VOC-contaminated aquifer: site characterization, experimental setup, and overview of results, J. Contam. Hydrol., 41(1-2), 81-131.

McCray, J.E., Tick., G.R., Jawitz, J.W., Gierke, J.S., Brusseau, M.L., Falta, R.W., Knox, R.C., Sabatini, D.A., Annable, M.D., Harwell, J.H., and Wood, A.L., 2011, Remediation of NAPL sources: lessons learned from field studies at hill and dover AFB, Ground Water, 49(5),727-744.

McGuire, T.M., Newell, C.J., Looney, B.B., Vangelas, K.M., and Sink, C.H., 2004, Historical analysis of monitored natural attenuation: A survey of 191 chlorinated solvent sites and 45 solvent plumes, Remediation, 15(1), 99-112.

McGuire, T.M., McDade, J.M., and Newell, C.J., 2006, Performance of DNAPL source depletion technologies at 59 chlorinated solvent-impacted sites, Ground Water Monit. Rem., 26(1), 73-84.

Phillips, D.H., Nooten, T.V., Bastiaens, L., Russell, M.I., Dickson, K., Plant, S., Ahad, J.M.E., Newton, T., Elliot, T., and Kalin, R.M., 2010, Ten year performance evaluation of a fieldscale zero-valent iron permeable reactive barrier installed to remediate trichloroethene contaminated groundwater, Environ. Sci. Technol., 44(10), 3861-3869.

Rivett, M.O., Chapman, S.W., Allen-King, R.M., Feenstra, S., and Cherry, J.A., 2006, Pump-and-treat remediation of chlorinated solvent contamination at a controlled field-experiment site, Environ. Sci. Technol., 40, 6770-6781.

Soga, K., Page, J.W.E., and Illangasekare, T.H., 2004, A review of NAPL source zone remediation efficiency and the mass flux approach, J. Hazard. Mater., 110(1-3), 13-27.

Wei, Y.-T., Wu, S.-C., Chou, C.-H., Tsai, S.-M., and Lien, H.-L., 2010, Influence of nanoscale zero-valent iron on geochemical properties of groundwater and vinyl chloride degradation: A field case study, Water Res., 44, 131-140.

Yang, J.-H., Jun, S.-C., Kwon, H.-P., and Lee, K.-K., 2013, Tracing of residual multiple DNAPL sources in the subsurface using ${ }^{222} \mathrm{Rn}$ as a natural tracer at an industrial complex in Wonju, 
Korea, Environ. Earth Sci., Published online.

Yang, J.-H., Lee, K.-K., and Clement, T.P., 2012, Impact of seasonal variations in hydrological stresses and spatial variations in geologic conditions on a TCE plume at an industrial complex in wonju, Korea, Hydrol. Process., 26(3), 317-325. 